\title{
Pulmonary Dysfunction Augmenting Bacterial Aerosols in Leather Tanneries of Punjab, Pakistan
}

\author{
Fiza Sarwar ${ }^{\prime}$ \\ Khan Alam ${ }^{2}$ \\ Chung Wai Chow ${ }^{3}$ \\ Muhammad Saeed' \\ Riffat Naseem Malik' \\ 'Environmental Biology and \\ Ecotoxicology Laboratory, Department \\ of Environmental Sciences, Quaid-i-Azam \\ University, Islamabad, Pakistan; \\ ${ }^{2}$ Department of Physics, University of \\ Peshawar, Peshawar, Pakistan; ${ }^{3}$ Dalla Lana \\ School of Public Health, Faculty of \\ Medicine, University of Toronto, Toronto, \\ Canada
}

Background: Particulate matter-associated microbes in the workplace are a burning issue in occupational toxicology. Studies have reported on respiratory infections among tannery cohorts. This study uniquely presents measurements of airborne bacterial concentrations associated with varied particulate-matter sizes, their exposure, and consequent severity in occupational respiratory problems, all for different microenvironments within leather tanneries.

Methods: Analyses included molecular identification of isolates, computation of mass median aerodynamic diameter of aerosols, tannery process-exposure dose (TPED) to bacterial aerosols, and spirometry and symptom assessment of impaired pulmonary function.

Results: The highest bacterial concentrations were for rawhide treatment and finishing units, showing $3.6 \times 10^{3}$ and $3.7 \times 10^{3} \mathrm{CFU} / \mathrm{m}^{3}$, respectively. Identified bacterial species included Ochrobactrum pseudogrignonense, Neisseria bacilliformis, Enterobacter cloacae, Alcaligenes faecalis, Klebsiella pneumoniae, and Corynebacterium spp. Maximum and minimum values of mass median aerodynamic diameter were $8.3 \mu \mathrm{m}$ and $0.65 \mu \mathrm{m}$ for buffing and snuffing and production units, respectively. The highest TPED was 1,516.9 $\mathrm{CFU} / \mathrm{kg}$ for finishing units. Respiratory symptoms in order of incidence were dyspnea $>$ phlegm $>$ cough $>$ wheezing and tachypnea (equivalent). Bronchodilator measurements of $\mathrm{FEV}_{1}, \mathrm{FVC}$, and PEF represent decline in lung function. Of 26 patients identified with COPD, most were working in rawhide treatment.

Conclusion: We conclude that exposure-infection synergy is also a cause of pulmonary ailments and COPD development, rather than the better-known exposure-smoking synergy. Keywords: respiratory symptoms, bacteria, lung function, COPD, tannery process, MMAD, infection, airborne

\section{Plain Language Summary}

Industrial exposure to particulate matter (PM) is a notorious source of occupationally induced respiratory ailments. In the interests of finding the synergistic effect of this chemical multimix PM with work-related microorganisms, this study presents interesting data on leather tanneries, showing a strong relationship of respiratory pathogenic bacterial in inhaled PM with enhancement of occupational respiratory disorders (eg, COPD and decline in FEV and FVC) and symptoms (dyspnea, phlegm, cough, wheeze and tachypnea) that exposed cohorts generally face even without bacterial infection. Further, instead of only airborne concentrations, mass median aerodynamic diameter of aerosols and tannery process-exposure doses are presented for different process sites within tanneries to identify the most riskprone. A majority of identified bacteria in PM were opportunistic pulmonary pathogens, the origin of which may be attributed to hides and skins under treatment and indoor environmental conditions in the workplace. 


\section{Graphical Abstract}

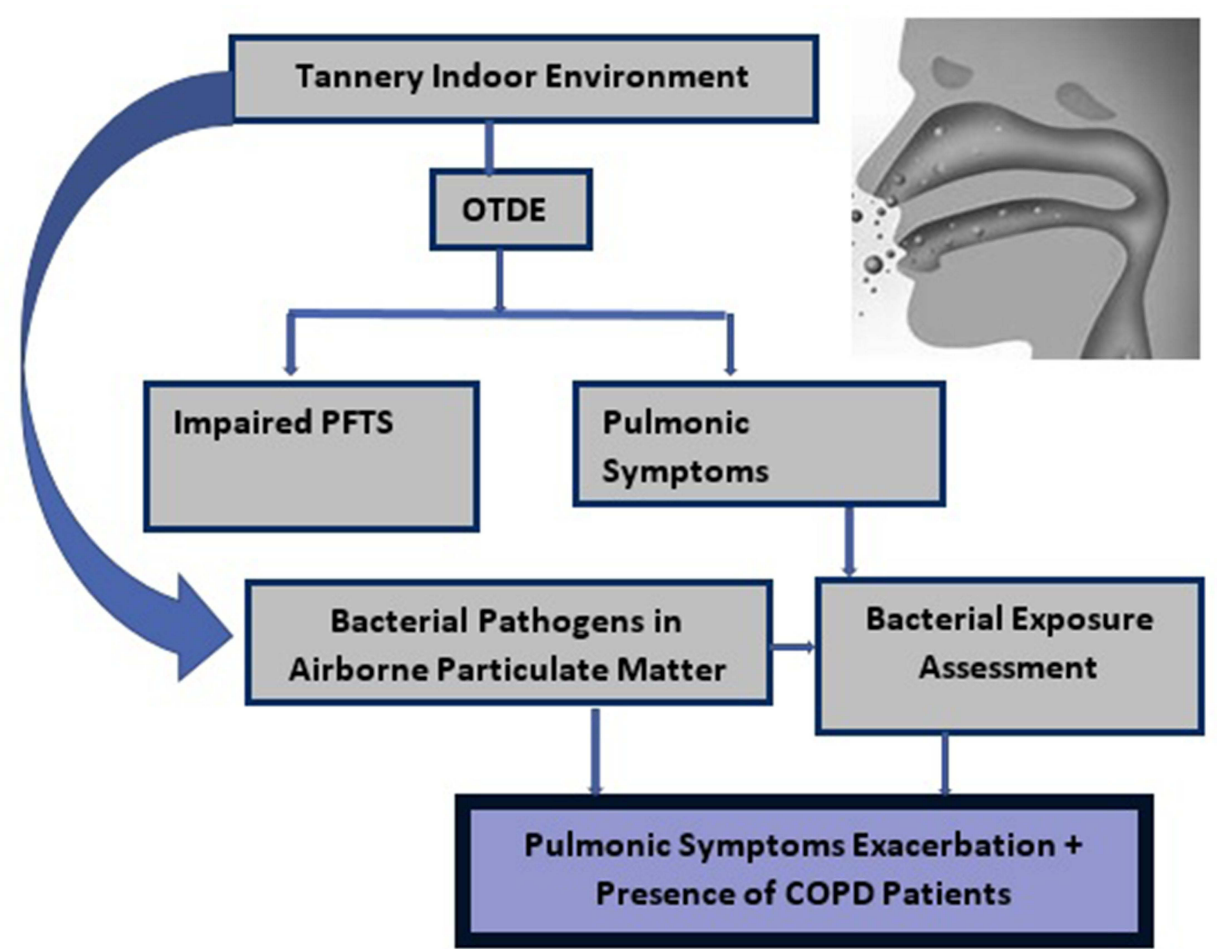

\section{OTDE: Occupational tannery dust exposure, PFTs: Pulmonary function} tests, COPD: Chronic obstructive pulmonary disease.

\section{Introduction}

Organic dust originates from plants, animals, and microbes. ${ }^{1}$ In workplaces, dispersed dust aerosols containing bacteria, viruses, and fungus spores located in the breathing zone of workers pose a particular danger to health. ${ }^{2}$ The distinct impacts of inhaled bioaerosols and particulates are known to cause respiratory ailments. However, synergistic impacts include exacerbation of pulmonary diseases, ${ }^{3}$ irritation of mucous membrane, organic dust toxic syndrome, asthma, allergic rhinitis and alveolitis, and COPD. ${ }^{4,5}$ Bacteria can be observed in many occupational environments. Bacterial pathogens are classified as fine biological particles within indoor dust. Ultrafine particles do not include bacteria, because a single bacterium is more than a micrometer in diameter. Nevertheless, bacteria-derived substances like lipopolysaccharide are common in airborne ultrafine particles, ${ }^{6}$ comprising almost
$5 \%-34 \%$ of indoor air pollutants. ${ }^{7}$ Gram-negative bacteria have lipopolysaccharide in cell walls that play a direct role in development of disease. ${ }^{8}$ Exposure to lipopolysaccharide and extracellular vesicles causes the creation of proinflammatory and immunomodulating factors. ${ }^{6}$ An invasion of neutrophils into the lower respiratory tract is a representation of this response, accompanied by production of inflammatory intermediaries. However, the inflammation declines after recurring exposure. ${ }^{9}$

A majority of occupational respiratory disorders are caused by dusts and gases, but many pulmonary infections have also been reported lately, eg, acquired by inhaling physical vectors like airborne particulates or droplets. ${ }^{10}$ A measure of bacterial concentration in an environment is not the only determinant of a pathogen's potential to induce problems among exposed personnel. In this regard, particle-size distribution and the bacterial concentration 
that is bioavailable to reach target tissue in human body is important. The quantity of pollutants actually invading through tissue by crossing biological barriers is called the dose. Occupational exposure limits (OELs) for bioaerosol doses have not been established yet, ${ }^{11}$ for there exists greate variation in workplace characteristics (ventilation type, open or closed workstations), individual vulnerability, and personal exposure levels. ${ }^{12}$

In leather tanneries, bioaerosols come primarily from skin dehairing and defleshing processes. Organic particulates originateing from animals (skin, hair, fur) are irritants of the upper respiratory tract, eyes, and skin. Small fractions are capable of reaching the lower respiratory tract and may cause diseases like bronchitis, asthma, conjunctivitis, and dermatitis, ${ }^{13}$ which have been reported among tannery employees. Animal hides facilitate growth of bacteria due to rich nutrients and high moisture content. Indoor air during tanning processes is associated with spread of microbes that lead to occupationally induced infections in employees. In buffing dust, fungal species have also been reported, ${ }^{14}$ which is also a major problem in hide-preservation units. In tanneries, major sources include fragments and fiber remnants from animal fur, skin, leather, brooms, protein-bound buffing dust, and organic tanning emissions. Animal skin provides an ideal medium for the propagation of microorganisms in both the leather-tannery and footwear industries. ${ }^{15}$ It has been found that the prevalence of symptoms suggestive of asthma, tuberculosis, and chronic bronchitis among tannery workers is higher than non-tannery workers. ${ }^{16}$ These symptoms include wheezing, obstructive lung disease, tightness of chest, difficulty in breathing, cough, and breathlessness after a walk. ${ }^{17}$ Increasing evidence suggests that the lung microbiome plays an important role in COPD severity. COPD is a pulmonary ailment that primarily develops with age, but environmental exposure and genetics are also considered significant disease-inducing agents. ${ }^{18}$

Acute exacerbations of COPD are sudden worsening of symptoms in which bacterial colonization is one major etiological factor. ${ }^{19}$ Bacteria have been isolated from the lower airways of stable COPD patients, and airway inflammation has been related to bacterial load and type. Bacterial colonization in COPD is an important factor in disease progression. ${ }^{20} \mathrm{COPD}$ is defined by the spirometric definition of postbronchodilator $\mathrm{FEV}_{1} / \mathrm{FVC}<0.7 .^{21}$ When calculating $\mathrm{FEV}_{1} / \mathrm{FVC}$, the highest value of each after reversibility testing is used, as per ERS taskforce guidelines for epidemiological studies on $\mathrm{COPD}^{22}$ and supported by GOLD guidelines. $^{23}$ The second definition (FEV1/FVC $<$ LLN) is not used, because compared to the first $\left(\mathrm{FEV}_{1} / \mathrm{FVC}\right.$ $<0.7$ ), no substantial connection has been found with this definition when respiratory assessments for exposure to biological dust, mineral dust, gases, and fumes ware made. ${ }^{24}$

It is well proven that bacteria play an important role in pulmonary obstructions and infections. There exists a gap in the available research regarding process-wise identification of respiratory pathogenic bacterial strains and consequent disorders at leather tanneries. Further, the available literature focuses on airborne bacterial concentrations in occupational environments, but little has been reported on bacterial mass or particle-size association. ${ }^{4}$ We hypothesized that tannery workers engaged in areas of high-level bioaerosol emissions would experience exacerbated particulate matter (PM)-associated pulmonary dysfunctions, as respiratory pathogens might play a synergistic role. Therefore, we aimed to gauge the presence of such bacteria in a variety of tannery environments by measuring viable culturable counts of bacteria in ambient air, the mass median aerodynamic diameter (MMAD) of bacterial aerosols, and the tannery process-exposure dose (TPED) of bacterial aerosols, and assess pulmonary function among tannery workers, along with pulmonary symptoms and enhancement during bacterial infections, and identify COPD patients among employees for a number of tannery microenvironments with different processes in progress.

\section{Methods}

Leather tanneries in Pakistan are not complete industrial units. Therefore, different processes are found in different factories. These processes are classified in groups on the basis of their being performed under one roof and thus environmental samples not being segregated. The process clusters identified for this study are shown in Table 1, representing a variety of microenvironments with different occupational exposure. Measurements were made in summer (July-September). Though the season was not at its peak, all routine processes were in progress. Representative samples were taken from leather tanneries of Lahore, Sialkot, and Kasoor, all renowned tannery hubs in Punjab.

\section{Bacterial Analysis \\ Air Sampling of Particulate Matter-Associated Bacteria}

Sampling was carried out using a portable 11.B aerosol spectrometer (Grimm Aerosol Technik Ainring). This 
Table I Tannery-site characteristics

\begin{tabular}{|l|l|l|}
\hline & Processes & Type \\
\hline $\begin{array}{l}\text { Rawhide } \\
\text { treatment }\end{array}$ & $\begin{array}{l}\text { Soaking, liming, dehairing, defleshing, } \\
\text { deliming, bating, and pickling }\end{array}$ & Sheltered \\
\hline $\begin{array}{l}\text { Wet machine } \\
\text { operations }\end{array}$ & $\begin{array}{l}\text { Chrome tanning, wet-blue storage, wet } \\
\text { finishing (wet back, neutralization, } \\
\text { retanning, washing, fat liquoring, dyeing, } \\
\text { and washing) }\end{array}$ & Indoor \\
\hline $\begin{array}{l}\text { Buffing and } \\
\text { snuffing }\end{array}$ & Buffing and snuffing & Indoor \\
\hline $\begin{array}{l}\text { Splitting and } \\
\text { shaving }\end{array}$ & Splitting and shaving & Sheltered \\
\hline $\begin{array}{l}\text { Production } \\
\text { unit }\end{array}$ & - & Indoor \\
\hline Finishing unit & $\begin{array}{l}\text { Hydraulic press, roller cutting, spray } \\
\text { plant }\end{array}$ & Indoor \\
\hline $\begin{array}{l}\text { Packing and } \\
\text { sales }\end{array}$ & $\begin{array}{l}\text { Weighing, finished leather trim, sorting, } \\
\text { and packing }\end{array}$ & Indoor \\
\hline
\end{tabular}

instrument has 31 size channels ranging from 0.25 to 32 $\mu \mathrm{m}$. Its working principle is light scattering of a single particle with a semiconductor laser as a light source of 638 $\mathrm{nm}$. Instead of filters, a greased glass slide was used as an impactor that collected aerosols. Samples were collected at a flow rate of $1.2 \mathrm{~L} / \mathrm{min}$. The sampler operated for 8 hours/ day for 3 days at each site to collect triplicate samples. These glass-slide samples for each process under investigation were taken to the laboratory using sterile isolated containers. $^{25}$ The collected samples were incubated at $30^{\circ} \mathrm{C}$, and colony-forming units (CFUs) were counted after 24 hours. Tryptic soy agar (Sigma-Aldrich) with $0.2 \%$ nystatin was used for collection of bacteria. Based on colony morphology, mixed-culture plates were then subcultured to obtain pure colonies.

\section{Molecular Identification of Isolates}

Confirmation of the isolated bacterial strains was done by molecular characterization through $16 \mathrm{~S}$ rRNA gene sequencing. Genomic DNA of all bacterial strains was obtained using a DNA-extraction kit (Qiagen). Concentrations of DNA were qualified and quantified by spectrometry using a NanoDrop 2000 (Thermo Fisher Scientific). PCR amplification of extracted DNA was done using universal bacterial primers $27 \mathrm{~F}^{\prime}$ (5'AGAGTTTGATCCTGGCTCAG-3') and 1492R' (5-CTACGGCTACCTTGTTACGA-3'). The PCR mixture consisted of GoTaq green master mix $(25 \mu \mathrm{L})$, primer $27 \mathrm{~F}^{\prime}$ $(1 \mu \mathrm{L})$, primer $1492 \mathrm{R}^{\prime}(1 \mu \mathrm{L})$, DNA extract $(2 \mu \mathrm{L})$, and nuclease-free water $(50 \mu \mathrm{L})$. An MJ Mini personal thermal cycler was used for the PCR reaction (Bio-Rad). Cycling conditions consisted of initial denaturation at $95^{\circ} \mathrm{C}$ for 3 minutes followed by 30 cycles of denaturation at $95^{\circ} \mathrm{C}$ for 1 minute, annealing at $55^{\circ} \mathrm{C}$ for 1 minute, and extension at $72^{\circ} \mathrm{C}$ for 1 minute. At $72^{\circ} \mathrm{C}$, the final extension was performed for 7 minutes. Electrophoresis was done for PCR-product analysis with $1 \%$ agarose gel. Sequencing of the amplified PCR product was done by Macrogen Service Center (Seoul, South Korea).

\section{MMAD and TPED}

The mass held in each particle size defines a particle population. The MMAD basically splits the distribution of the mass in half. During respiration, there is maximum chance of particles $\leq 3 \mu \mathrm{m}$ reaching the lower respiratory tract of an adult. ${ }^{26}$

MMAD was calculated using:

$$
M M A D=\sum \text { midi } / M
$$

where $\mathrm{mi}$ is the mass of all particles in one group $\mathrm{i}$ (where $\mathrm{d}$ is the midpoint dimeter).

The TPED was measured for indoor and semi-indoor environments $(\mathrm{CFU} / \mathrm{kg}):^{12}$

$$
T P E D=C \cdot I R \cdot I E F / B W
$$

where $\mathrm{C}$ is the bacterial aerosol concentration $\left(\mathrm{CFU} / \mathrm{m}^{3}\right)$, IEF the indoor exposure fraction (hours spent per day at work considering assorted activity patterns), IR the inhalation-rate coefficient characteristic of the selected activity levels $\left(\mathrm{m}^{3} /\right.$ day) ${ }^{27}$ and BW mean body weight $(\mathrm{kg})$.

\section{Pulmonary Assessment of Workforce Inclusion and Exclusion Criteria}

A total of 250 male workers aged 18-60 years engaged at tannery works for at least 5 years in the same microenvironment were recruited as subjects. Those diagnosed with respiratory or other ailments like anemia, abnormal vertebral column or thoracic cage, diabetes, respiratory tuberculosis, asthma, and bronchitis and those severely ill were excluded from the study. Further the drug buffs, tobacco consumers were also omitted from the study. Smokers and nonsmokers were included and compared, as cigarette smoking is considered an important factor in the development of pulmonary ailments and occupational COPD. ${ }^{28}$ 


\section{Spirometry}

Spirometry was performed in leather tanneries in Lahore, Kasur and Sialkot.

A handheld digital spirometer (SP10W, Contec) was used to record $\mathrm{FEV}_{1}, \mathrm{FVC}$, and $\mathrm{FEV}_{1} \%\left(\mathrm{FEV}_{1} / \mathrm{FVC}\right)$, both pre- and postbronchodilation. For validation and accuracy of testing, equipment quality control was carried out with regular calibration checks before testing was performed, according to American Thoracic Society

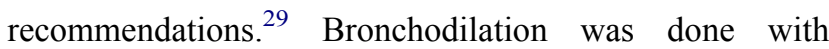
a combination of $0.4 \mathrm{mg}$ salbutamol and 80 $\mu \mathrm{g}$ ipratropium bromide. $^{23} \mathrm{FEV}_{1}$ and $\mathrm{FVC}>80 \%$ is considered normal, $\mathrm{FEV}_{1}$ and $\mathrm{FVC}<80 \%$ but $\mathrm{FEV}_{1} /$ FVC $>0.7$ represents restriction, and $\mathrm{FEV}_{1}<80 \%$ with reduced FVC shows obstruction. ${ }^{30}$ Subjects with COPD were classified into grades $1-4$ according to GOLD. ${ }^{31}$ The GOLD classification of airflow-limitation severity in COPD (based on postbronchodilator $\mathrm{FEV}_{1}$ ) is 1 (mild) = $\mathrm{FEV}_{1} \geq 80 \%$ predicted 2 (moderate) $=50 \% \leq \mathrm{FEV}_{1}<80 \%$ predicted, 3 (severe) $30 \% \leq \mathrm{FEV}_{1}<50 \%$ predicted, and 4 (very severe) $\mathrm{FEV}_{1}<30 \%$ predicted.

\section{Pulmonary Symptom Assessment}

A standard pulmonary symptom-identification questionnaire was filled in by all subjects. Symptoms included cough, phlegm, chest troubles, tachypnea, dyspnea, and wheezing. ${ }^{32}$ It was also modified to include if these symptoms were associated with routine exposure and/or enhanced with chest bacterial infections. Division of 8 working hours was also determined based on activity level via a walk-through survey for each process.

\section{Statistical Analysis}

Two sample $t$-tests were used to find statistical contrasts in pulmonary symptoms when conditions shifted from only dust-exposure days to the days when working cohorts experience increased respiratory infection with occupational dust exposure. Multiple linear (forward) regression models were used to identify predictor variables for cough, wheezing, tachypnea, dyspnea, and phlegm. For the chosen covariates, $P<0.1$ was utilized to locate variables for the best-fit model to explain the highest variations in dependent variables. Differences were considered statistically significant at $P<0.05$. SPSS 21.0 was employed for statistical analysis.

\section{Results and Discussion}

\section{Bacteria in Tannery Dust}

Tanneries in Pakistan perform different operations, ie, a complete chain of processes is not found in a single factory. That is why processes at all locations were clustered and considered as one workplace to collect data. Table 2 presents the bacteria identified along with reported characteristics from the literature and pulmonary pathogenicity.

Ten strains were observed, of which one was uncultured. Noviherbaspirillum autotrophicum is found in air of three units: wet operations, rawhide treatment, and splitting and shaving. This facultatively autotrophic bacterium was reportedly isolated from rice-paddy soil. ${ }^{33}$

Alcaligenes spp. were found where splitting and shaving of hides and skins was in progress. These drug-resistant respiratory pathogens ${ }^{34,35}$ may worsen pulmonary infections. Compromised respiratory tracts become victims of this opportunistic pathogen. Three strains of this family were identified, of which two were Alcaligene faecalis. Ochrobactrum pseudogrignonense was isolated from aerosols collected from rawhide treatment, spraying and finishing, and packing and production units. This is a known human respiratory pathogen that has frequently been found in patients with cystic fibrosis. ${ }^{36}$ This emergent pathogen is equally treacherously infectious for both immunocompromised and healthy humans. ${ }^{37}$ Neisseria bacilliformis is also an opportunistic pathogen that causes infection in the upper respiratory tract. ${ }^{38}$ In this study, it was found in skin-splitting and -shaving and leather-finishing units. Enterobacter cloacae is a Gram-negative anaerobic facultative bacteria that causes human infections of the respiratory tract, urinary tract, skin, and abdomen. ${ }^{39}$ The basic source for its emergence in the tannery environment is the skin and hides of animals. It was found in the air of a finishing unit. Klebsiella pneumoniae is specifically a respiratory and urinary tract infectant; however, it may cause infection in any part of the body. It colonizes and multiplies in the gastrointestinal tract, and a majority of infections arise when bacteria move from the here. ${ }^{40}$ Corynebacterium spp. are multidrug-resistant bacteria, of which the first epidemic was reported in of COPD patients in 2007. These organisms cause infection that worsens existing respiratory disorders. ${ }^{41}$ Providencia rettgeri, isolated from the air of a finishing unit is not a respiratory infectant, but causes urinary tract and skin infections in humans. ${ }^{42}$ 
Table 2 Human pulmonary bacterial pathogens isolated from tannery air

\begin{tabular}{|c|c|c|c|c|}
\hline & Family & Characteristics & $\begin{array}{l}\text { Pulmonary symptoms from } \\
\text { literature }\end{array}$ & References \\
\hline $\begin{array}{l}\text { Noviherbaspirillum } \\
\text { autotrophicum }\end{array}$ & Oxalobacteraceae & $\begin{array}{l}\text { Facultatively autotrophic } \\
\text { bacterium isolated from rice } \\
\text { paddy soil }\end{array}$ & NA & Ishii et $\mathrm{al}^{33}$ \\
\hline \multirow[t]{3}{*}{ Alcaligenes spp. } & \multirow[t]{3}{*}{ Alcaligenaceae } & \multirow{3}{*}{$\begin{array}{l}\text { Opportunistic respiratory } \\
\text { pathogens }\end{array}$} & Adult respiratory distress syndrome & \multirow[t]{3}{*}{ Aisenberg et $\mathrm{al}^{34}$} \\
\hline & & & Sepsis syndrome & \\
\hline & & & Cystic fibrosis & \\
\hline \multirow{3}{*}{$\begin{array}{l}\text { Ochrobactrum } \\
\text { pseudogrignonense }\end{array}$} & & \multirow{2}{*}{$\begin{array}{l}\text { Opportunistic respiratory } \\
\text { pathogens }\end{array}$} & Cystic fibrosis & \multirow{3}{*}{$\begin{array}{l}\text { Lundy et al, } \\
\text { Chmelař, Holý } \\
\text { et } \mathrm{al}^{36,64}\end{array}$} \\
\hline & & & Respiratory failure & \\
\hline & & No cross-contamination & $\begin{array}{l}\text { Upper and lower respiratory tract } \\
\text { infections }\end{array}$ & \\
\hline Neisseria bacilliformis & Neisseriaceae & \multirow[t]{4}{*}{ Opportunistic pathogens } & Upper respiratory tract infections & Han et $\mathrm{al}^{38}$ \\
\hline \multirow[t]{3}{*}{ Enterobacter cloacae } & \multirow[t]{3}{*}{ Enterobacteriaceae } & & COPD & \multirow{3}{*}{$\begin{array}{l}\text { Didilescu et al, } \\
\text { Miyoshi-Akiyama } \\
\text { et } \mathrm{al}^{49,50}\end{array}$} \\
\hline & & & Nosocomial pneumonia & \\
\hline & & & Lower respiratory tract pneumonia & \\
\hline \multirow[t]{3}{*}{$\begin{array}{l}\text { Alcaligenes faecalis } \\
\text { (two strains) }\end{array}$} & \multirow[t]{3}{*}{ Alcaligenaceae } & \multirow{2}{*}{$\begin{array}{l}\text { Pan-drug-resistant organism even } \\
\text { to carbapenems, polymyxins, and } \\
\text { tigecycline }\end{array}$} & $\begin{array}{l}\text { Respiratory depression (reduced } \\
\mathrm{SPO}_{2} \text { ) }\end{array}$ & \multirow[t]{3}{*}{$\begin{array}{l}\text { Kavuncuoglu et al, } \\
\text { Hasan et al }{ }^{35,63}\end{array}$} \\
\hline & & & Bloodstream infections & \\
\hline & & Respiratory dysfunction synergist & Acute respiratory distress syndrome & \\
\hline \multirow[t]{2}{*}{ Klebsiella pneumoniae } & \multirow[t]{2}{*}{ Enterobacteriaceae } & \multirow[t]{2}{*}{ Opportunistic pathogen } & Lung and urinary tract infection & \multirow[t]{2}{*}{ Kaur et a ${ }^{62}$} \\
\hline & & & Gastrointestinal diseases & \\
\hline \multirow[t]{2}{*}{ Corynebacterium spp. } & & Animal-skin flora & \multirow[t]{2}{*}{ Respiratory infections } & \multirow{2}{*}{$\begin{array}{l}\text { Díez-Aguilar } \\
\text { et } \mathrm{al}^{4 !}\end{array}$} \\
\hline & & Human pathogen & & \\
\hline Providencia rettgeri & Enterobacteriaceae & - & $\begin{array}{l}\text { Urinary tract infections, bacteremia, } \\
\text { skin infections, diarrhea, and } \\
\text { gastroenteritis }\end{array}$ & $\begin{array}{l}\text { Yoh et al, Tada } \\
\text { et } \mathrm{al}^{42,61}\end{array}$ \\
\hline
\end{tabular}

Four strains identified in this study have also been isolated from oropharyngeal mucosa of tannery workers in Mexico: Alcaligenes faecalis, Neisseria bacilliformis, Enterobacter cloacae, and Klebsiella pneumoniae, ${ }^{15}$ which confirms the association of these bacteria with the tannery environment. Table 3 gives a checklist of identified bacteria at different leather tanneries.

\section{MMAD and TPED}

MMAD values of the particle populations observed at defined sites are shown in Table 4. The maximum MMAD was measured for $\mathrm{B} \& \mathrm{~S}-8.3 \mu \mathrm{m}$. This means
$50 \%$ of the total sample mass is present in particles with aerodynamic diameter $<8.3 \mu \mathrm{m}$ and the other $50 \%$ in particles $>8.3 \mu \mathrm{m}$ in diameter. ${ }^{43}$ The minimum was 0.65 $\mu \mathrm{m}$, for PU. Commonly, bioaerosol size is $0.02-100 \mu \mathrm{m},{ }^{44}$ but their association with particulates changes the aerodynamic diameter of $\mathrm{PM}^{3}$ affecting their inhalation characteristics. The atmosphere shows a chemistry of two contrasting mechanisms in summer and spring. Bacteria grow quickly, but the particle-size range (fine) that is associated with bacterial mass tends to exterminate. Therefore, there are fewer fine particles $(<3.3 \mu \mathrm{m})$ in total particulates. ${ }^{45}$ The TPED results are also shown in 
Table 3 Site-wise bacteria identified

\begin{tabular}{|c|c|c|c|c|c|c|c|c|}
\hline & RHT & WMO & PU & FU-S & FU-HP & B\&S & S\&S & P\&S \\
\hline Noviherbaspirillum autotrophicum & $x$ & $x$ & - & - & - & - & $x$ & - \\
\hline Alcaligenes spp. & $x$ & - & - & - & - & $x$ & $x$ & - \\
\hline Ochrobactrum pseudogrignonense & $x$ & - & $x$ & $x$ & - & $x$ & - & $x$ \\
\hline Neisseria bacilliformis & & - & - & $x$ & $x$ & $x$ & $x$ & $x$ \\
\hline Enterobacter cloacae & $x$ & $x$ & - & $x$ & $x$ & $x$ & $x$ & $x$ \\
\hline Alcaligenes faecalis (two strains) & $x$ & - & - & $x$ & $x$ & - & $x$ & $x$ \\
\hline Klebsiella pneumoniae & $x$ & $x$ & $x$ & $x$ & $x$ & - & $x$ & $x$ \\
\hline Corynebacterium spp. & $x$ & - & - & $x$ & $x$ & $x$ & $x$ & $x$ \\
\hline Providencia rettgeri & $x$ & - & - & $x$ & $x$ & - & $x$ & $x$ \\
\hline Uncultured bacteria & $x$ & - & - & - & - & - & & - \\
\hline
\end{tabular}

Notes: $x$, presence; - , absence.

Table 4. Maximum TPED was 1,516.9 CFU/kg for FU-HP and the minimum was found for WMO $-92.78 \mathrm{CFU} / \mathrm{kg}$. One reason for exposure limits not yet being established for bioaerosols of occupational origin is that individual exposure characteristics and vulnerabilities are exceedingly varied. ${ }^{12}$

\section{Pulmonary Function}

The process-wise distribution of the 250 tannery workers was PS 55, RHT 48, WMO 37, BS+SS 64, and FU 46. They were all male Muslims and residents of the areas where their workplaces were located. Two-thirds (66\%) were married. Their awareness of occupational safety was medium (51\%), low (45\%), and high (4\%). Demographic characteristics are shown in Table 5. All were working for 8 hours a day.

\section{Spirometry and COPD}

Average process-based $\mathrm{FEV}_{1}, \mathrm{FVC}$, and PEF are shown in Figure 1. There were clear differences in between pre- and postbronchodilation. However, the most compromised lung function was found in $\mathrm{BS}+\mathrm{SS}$ personnel, because of being exposed to buffing dust, toggling dust in the hangdry process, and shaving and splitting producing fine and ultrafine dust. Their prebronchodilation $\mathrm{FEV}_{1}$ was 2.10 \pm 0.667 . However, considerable improvement was observed after bronchodilation $-2.62 \pm 0.492$. Similarly, prebronchodilation FVC was $2.48 \pm 0.746$ and became 2.96 \pm 0.951 after the reversibility test had been applied. This response to medication in the form of improvement in $\mathrm{FEV}_{1}, \mathrm{FVC}$, and PEF gives an indication of airway

Table 5 Demographic characteristics of participating workforce $(n=250)$

\begin{tabular}{|l|c|}
\hline Parameter & $\begin{array}{c}\text { Tannery workers } \\
\mathbf{N = 2 5 0}\end{array}$ \\
\hline Age (years) & $35 \pm 10.55$ \\
BMI & $23.73 \pm 4.77$ \\
Body weight $(\mathrm{kg})$ & $70 \pm 5.6$ \\
Smokers & $28.4 \%$ \\
Nonsmokers & $71.6 \%$ \\
\hline
\end{tabular}

Table 4 Bacterial concentrations, MMAD, and TPED

\begin{tabular}{|c|c|c|c|c|c|c|c|c|}
\hline & RHT & WMO & PU & FU-S & FU-HP & B\&S & S\&S & P\&S \\
\hline Bacterial concentration $\left(\mathrm{CFU} / \mathrm{m}^{3}\right)$ & $3.6 \times 10^{3}$ & $2.3 \times 10^{2}$ & $2.6 \times 10^{2}$ & $3.2 \times 10^{3}$ & $3.7 \times 10^{3}$ & $3.2 \times 10^{3}$ & $2.8 \times 10^{3}$ & $2.2 \times 10^{3}$ \\
\hline \multicolumn{9}{|c|}{$\begin{array}{l}\text { Tolerable concentrations of airborne microbes in occupational environment: } \\
\text { Mesophilic bacteria 100,000 and Gram-negative bacteria } 20,000 \\
\text { Suggested standards for respirable aerosols are half those, ie, } 50,000 \mathrm{CFU} / \mathrm{m}^{3} \text { for mesophilic bacteria and } 10,000 \mathrm{CFU} / \mathrm{m}^{3} \text { for Gram-negative } \\
\text { bacteria. }^{65}\end{array}$} \\
\hline $\operatorname{MMAD}(\mu \mathrm{m})$ & 7.740 & $0.74 I$ & 0.659 & 7.199 & 7.050 & 8.351 & 7.960 & 7.265 \\
\hline TPED (CFU/kg) & $\mathrm{I}, 464.4$ & 92.78 & 104.9 & $\mathrm{I}, 295$ & $1,516.9$ & 1,299 & 1,130 & 923.9 \\
\hline
\end{tabular}

Notes: Sheltered: (top covered corridor without walls); average work hours 8; average employee weight $70 \mathrm{~kg}$.

Abbreviation: MMAD, median mass aerodynamic diameter; TPED, tannery process-exposure dose. 


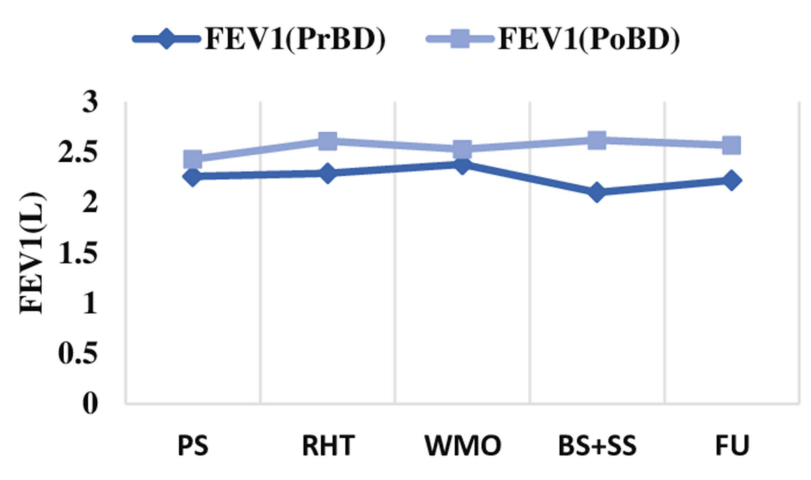

A

Tannery Process
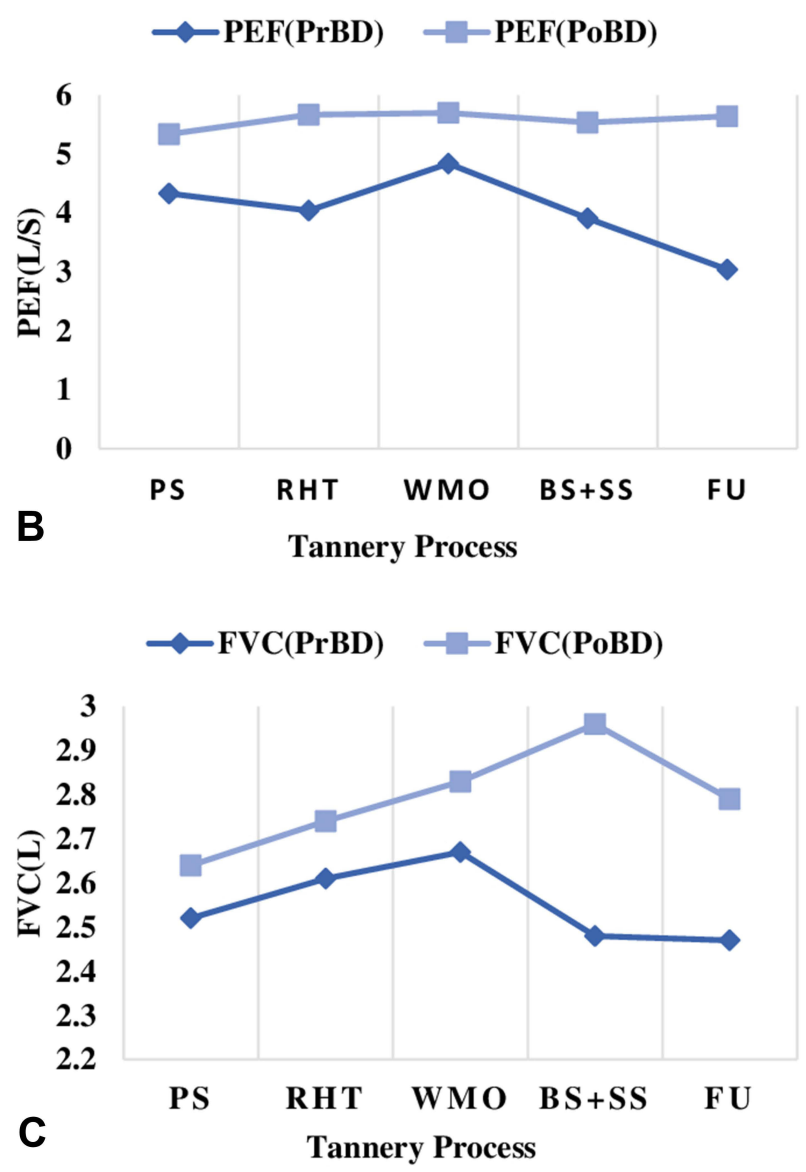

Figure I Process-based comparison of average pulmonary function in tannery workers. (A) PrBD and PoBD forced expiratory volume in one second $\left(\mathrm{FEV}_{1}\right)$; (B) PrBD and PoBD peak expiratory flow (PEF); (C) PrBD and PoBD forced vital capacity (FVC).

Abbreviations: PrBD, pre bronchodilation; PoBD, post bronchodilation.

obstruction. ${ }^{46}$ These results are parallel to those reported in the literature. ${ }^{9,17,46-48}$ Moreover, these are the processes where respiratory pathogenic bacteria have also been recognized, and surveyed pulmonary symptoms back this finding as well.

Although highly severe cases of COPD were not identified, for those suffering from COPD, GOLD stages were determined (Figure 2). Two COPD patients were identified in the B\&S group, of which one (nonsmoker) was stage 1and the other(smoker) stage 2. Similarly identified cases of COPD stages were shown for all sampled processes. Most were found in RHT (ten), including six smokers and two nonsmokers. A peculiar finding was one with stage 3 COPD being a nonsmoker. The overall trend was RHT (ten) $>\mathrm{SS}$ (5) $>\mathrm{PU}(4)>\mathrm{WMO}, \mathrm{P} \& \mathrm{~S}$, and $\mathrm{BS}$ (two each) $>\mathrm{FU}($ one) $>\mathrm{HD}$ (none). The highest stage of COPD was identified as stage 3 of which four worked in RHT and two in S\&S. These two environments presented the most COPD patients. It was also observed that the highest bacteria numbers, including pulmonary pathogens, ${ }^{49,50}$ were found in S\&S and RHT units. Since cigarette smoking is a known COPD-exacerbating agent, distribution of COPD patients was determined using this factor. An important aspect to be noted is that the COPD patients identified were not necessarily smokers. It is may be because cigarette smoking is not the only risk factor of pulmonary obstructions. ${ }^{51,52}$ This ailment may grow among nonsmokers due to their exposure to dust and infectious agents. Nonsmokers can also develop chronic airflow obstruction, and smokers show substantially inconsistent vulnerability when it comes to symptoms and signs of pulmonary obstruction, ${ }^{53}$ which may be attributed to recurring exposure to a variety of tannery dusts along with pulmonary obstruction-aggravating bacteria. In a recent study on causative agents of COPD exacerbation, 55 noninfectious, 33 bacterial, and 12 bacterial agents were found. Of 33, nine patients had Klebsiella pneumoniae, ${ }^{54}$ which was identified in PM sampled from all processes, except for B\&S.

\section{Bacterium-Induced Pulmonary Symptom Augmentation}

All the tannery working groups showed respiratory symptoms with considerably high percentages, as shown in Table 6 (dyspnea $>$ phlegm $>$ cough $>$ wheezing and tachypnea [equivalent]). These symptoms are induced occupationally by prolonged exposure to chemical-laden particulates emitted from different tannery processes. ${ }^{9,55-}$ ${ }^{57}$ Respirational indicators like chest pain, cough, dyspnea, cough, and phlegm among tannery workers are symptoms of pulmonary dysfunction. ${ }^{58}$ It was quite observable that among recorded respiratory symptoms, a majority were enhanced when exposure is synergized with chest infection. This supports that dust-induced occupational respiratory symptoms being boosted in coexistence with respiratory infection causing bacteria. Both chronic and developing pulmonary obstructions are intensified by 


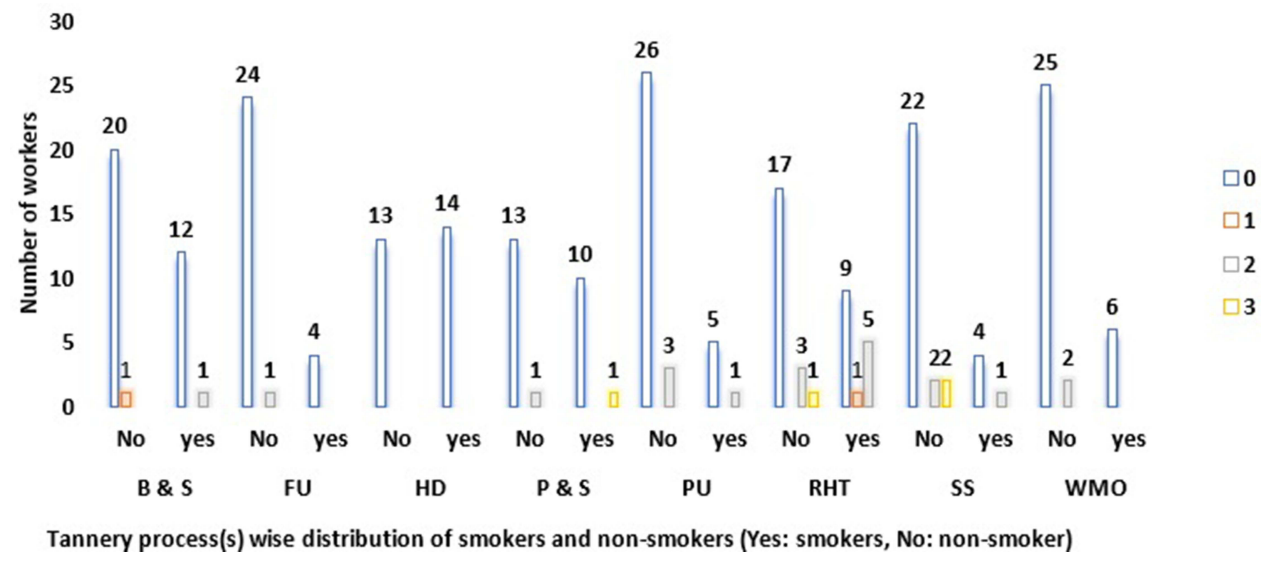

Figure 2 Stagewise (GOLD) distribution of COPD patients among tannery-workier cohorts: difference for smokers and nonsmokers. 0, no disease; I, GOLD stage I; 2 , GOLD stage 2; 3, GOLD stage 3.

bronchial infections, and result in acute increases in symptoms like cough, dyspnea, and phlegm. ${ }^{59}$ Further, upon bacterial respiratory infection, differences in symptoms between smokers and nonsmokers were recorded. The results showed increased magnitude of symptoms among nonsmokers (cough 24.8\%, phlegm 18.0\%, wheeze 15.2\%, dyspnea $14.0 \%$ ) compared to smokers (cough 1.6\%, phlegm $6.4 \%$, wheeze $5.2 \%$, dyspnea 5.6\%). Studies have reported symptoms among tannery workers of dry/ productive cough, throat irritation, dyspnea, and chest troubles. 9,60 So far, these symptoms have been reported without work/process specification or evaluation of exposure-induced symptoms vs symptoms synergized by bacterial infections. This study presents these assessments (Table 6A), where (except for tachypnea) differences in symptoms between two investigated conditions was statistically apparent. Further, it was identified that no independent variables, including process and smoking, had a significant impact on cough (only exposure) and wheeze (only exposure). The forward-regression model identified significant contributors to each pulmonary symptom, as presented in Table 6B. During exposure and infection, cough was found to be highly influenced by presence of bacteria and bacteria numbers $\left(R^{2}=0.023\right.$, $P=0.01)$. A similar trend was observed for the other pulmonary parameters. However, for tachypnea, two variables (department types and bacteria numbers) were found to have an influence on exposure to infection conditions $\left(R^{2}=0.033, P=0.002\right)$. From these models, it can be inferred that the presence of bacteria was the highest contributor in enhancing respiratory symptoms like coughing, wheezing, and dyspnea.
This study is a pioneer in determining the synergy of occupational exposure of PM and bacterial pathogens in aggravating respiratory conditions in different microenvironments of leather tanneries. Implications of this study may be useful for studying synergy with chemical characteristics of PM. Further, the inclusion of both sexes as study subjects may widen the horizon of the subject matter.

\section{Conclusion}

From different microenvironments of leather tanneries, human respiratory pathogenic bacteria were associated with inhalable PM. According to MMAD computation, 50\% bacterial mass was associated with average PM size $>7 \mu \mathrm{m}$, except for WMO and PU, where this association was also substantial with PM $<0.5 \mu \mathrm{m}$. Some areas present alarming airborne concentrations and TPED. Our data show that work-environment exposure along with chest infections enhance respiratory symptoms manyfold. This points to the synergy of opportunistic respiratory pathogens with exposure to incidental PM at work. Obstructive variations on pulmonary functions $\mathrm{FEV}_{1}, \mathrm{FVC}$, and PEF and identification of COPD patients with grade 3 COPD also prove the compromised lung function of tannery workers. Bacterial infections were a stronger synergist with occupationally induced pulmonary symptoms than smoking, signifying the importance of setting up protective measures focusing on respiratory health among exposed workers, especially in departments like rawhide treatment, shaving and splitting, buffing, finishing, and packing.

\section{Data Sharing Statement}

All generated or analyzed data in this study are included in this manuscript. Additional information/data will be furnished by the corresponding authors upon request. 
Table 6 Statistical evidence of bacterial aerosol-tannery dust synergy enhancing pulmonary dysfunction

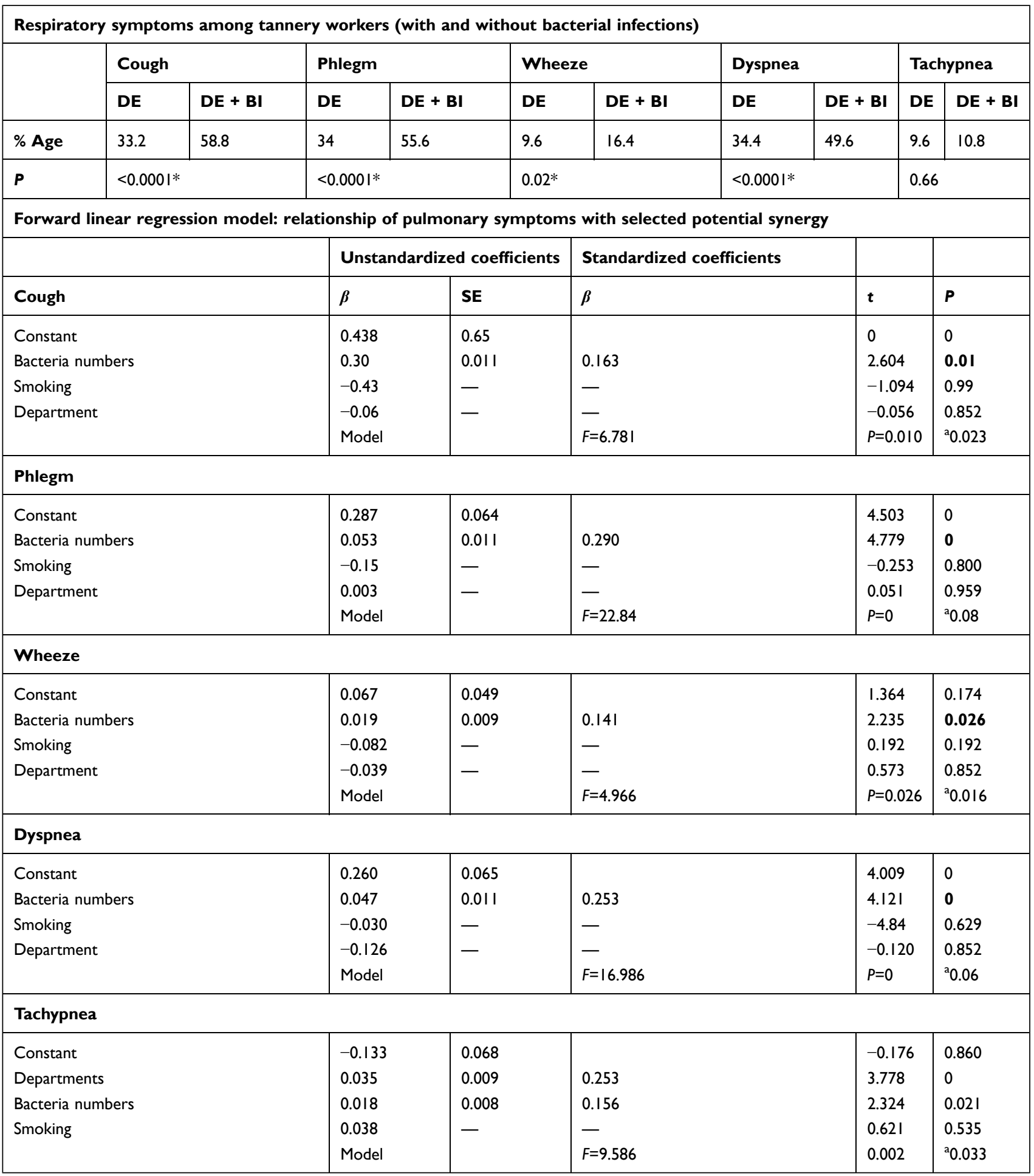

Notes: $* P=0.05$. ${ }^{2}$ Adjusted $R^{2}$. Independent variables: bacteria numbers, smoking status, and department type. $P$-values in bold indicate maximum influence on pulmonary symptom.

Abbreviations: DE, dust exposure (days); BI, bacterial infection (days). 


\section{Ethics}

This study was approved by the ethics review board of Quaid-i-Azam University, Islamabad. All participants were informed on the nature, purpose, and likely upshot of the study. Each participant signed a consent form prior to spirometry and questionnaire-based surveillance. The Declaration of Helsinki (revised 2013) was also complied with.

\section{Consent for Publication}

Informed consent was taken from all participants.

\section{Author Contributions}

All authors contributed to data analysis and drafting or revising the article, have agreed on submitting the article to this journal, gave final approval to the version to be published, and agree to be accountable for all aspects of the work.

\section{Disclosure}

The authors report no conflicts of interest in this study.

\section{References}

1. Peters S, Kromhout H, Olsson AC, et al. Occupational exposure to organic dust increases lung cancer risk in the general population. Thorax. 2012;67(2):111-116.

2. Shkrabak V, Popov A, Enikeev V, Gavrikova E, Shkrabak R. Indoor air decontamination system and reduction of microorganism emissions into the atmosphere; Paper presented at: BIO Web of Conferences; 2020.

3. Adhikari A, Reponen T, Grinshpun SA, Martuzevicius D, LeMasters G. Correlation of ambient inhalable bioaerosols with particulate matter and ozone: a two-year study. Environ Pollut. 2006;140(1):16-28.

4. Brągoszewska E, Pawlak M. Health risks associated with occupational exposure to biological air pollutants occurring during the processing of biomass for energy purposes: a case study. Energies. 2021;14(8):2086.

5. Gołofit-Szymczak, M., \& Lawniczek-Wałczyk, A. (2011). Biomass as a source of biological threats. Occupational Safety: Science and Practice, (12):17-19. Available from: https://www.infona.pl/resource/ bwmeta1.element.baztech-article-BPC1-0011-0009

6. Yang J, Kim EK, Park HJ, McDowell A, Kim Y-K. The impact of bacteria-derived ultrafine dust particles on pulmonary diseases. Exp Mol Med. 2020;52:1-10.

7. Srikanth P, Sudharsanam S, Steinberg R. Bio-aerosols in indoor environment: composition, health effects and analysis. Indian J Med Microbiol. 2008;26(4):302.

8. Kim Y-M, Kim Y-S, Jeon SG, Kim Y-K. Immunopathogenesis of allergic asthma: more than the th2 hypothesis. Allergy Asthma Immunol Res. 2013;5(4):189-196.

9. Işsever H, Özdilli K, Özyildirim BA, et al. Respiratory problems in tannery workers in Istanbul. Indoor Built Environ. 2007;16(2):177-183.

10. Ho P, Becker M, Chan-Yeung M. Emerging occupational lung infections [State of the Art Series. Occupational lung disease in high-and low-income countries, edited by M. Chan-Yeung. Number 6 in the series]. Int J Tuberc Lung Di. 2007;11(7):710-721.
11. Di Filippo P, Pomata D, Riccardi C, Buiarelli F, Perrino C. Fungal contribution to size-segregated aerosol measured through biomarkers. Atmos Environ. 2013;64:132-140.

12. Brągoszewska E, Biedroń I, Kozielska B, Pastuszka JS. Microbiological indoor air quality in an office building in Gliwice, Poland: analysis of the case study. Air Qual Atmos Health. 2018;11(6):729-740.

13. Buzea C, Pacheco II, Robbie K. Nanomaterials and nanoparticles: sources and toxicity. Biointerphases. 2007;2(4):MR17-MR71.

14. Emmanueul S, Adamu I, Ejila A, Ja'afaru M, Yabaya A, Habila B. Characterization of chrome buffing dust (CBD) generated from NILEST tannery associated with pathogenic fungi. $J$ Toxicol Environ Health Sci. 2014;6(3):89-98.

15. Castellanos-Arévalo DC, Castellanos-Arévalo AP, CamarenaPozos DA, Colli-Mull JG, Maldonado-Vega M. Evaluation of microbial load in oropharyngeal mucosa from tannery workers. Saf Health Work. 2015;6(1):62-70.

16. Kashyap GC, Sharma SK, Singh SK. Prevalence and predictors of asthma, tuberculosis and chronic bronchitis among male tannery workers: a study of Kanpur City, India. Clin Epidemiol Glob Health. 2020;9:71-77.

17. Jamal A, Mehmood A, Putus T, Savolainen H, Liesivuori J. Prevalence of respiratory symptoms, bronchial asthma and obstructive lung disease among tannery workers. Peertechz J Environ Sci Toxicol. 2017;2(1):33-42.

18. Martinez CH, Mannino DM, Divo MJ. Defining COPD-related comorbidities, 2004-2014. J COPD Foundation. 2014;1(1):51.

19. Wang Z, Bafadhel M, Haldar K, et al. Lung microbiome dynamics in COPD exacerbations. Eur Respir J. 2016;47(4):1082-1092.

20. Wilkinson TM, Patel IS, Wilks M, Donaldson GC, Wedzicha JA. Airway bacterial load and FEV1 decline in patients with chronic obstructive pulmonary disease. Am J Respir Crit Care Med. 2003;167(8):1090-1095.

21. Song JH, Lee C-H, Kim DK, et al. Differences in prevalence of asthma-COPD overlap according to different criteria. Medicine. 2018;97(36):e12049.

22. Bakke P, Rönmark E, Eagan T, et al. Recommendations for epidemiological studies on COPD. Eur Respir Soc. 2011;38:1261-1277.

23. Hagstad S, Backman H, Bjerg A, et al. Prevalence and risk factors of COPD among never-smokers in two areas of Sweden-occupational exposure to gas, dust or fumes is an important risk factor. Respir Med. 2015;109(11):1439-1445.

24. Alif SM, Dharmage SC, Bowatte G, et al. Occupational exposure and risk of chronic obstructive pulmonary disease: a systematic review and meta-analysis. Expert Rev Respir Med. 2016;10(8):861-872.

25. Pathak B, Borah D, Khataniar A, Bhuyan P, Buragohain A. Characterization of bioaerosols in Northeast India in terms of culturable biological entities along with inhalable, thoracic and alveolar particles. J Earth Syst Sci. 2020;129(1):1-13.

26. Dolovich MB, Dhand R. Aerosol drug delivery: developments in device design and clinical use. Lancet. 2011;377(9770):1032-1045.

27. Health USEPAOo, Group EAEA. Exposure Factors Handbook. Vol. 90. Office of Health and Environmental Assessment, US Environmental Protection; 1989.

28. Bepko J, Mansalis K. Common occupational disorders: asthma, COPD, dermatitis, and musculoskeletal disorders. Am Fam Physician. 2016;93(12):1000-1006.

29. Miller M, Hankinson J, Brusasco V, et al. Standardization of spirometry, 1994 update. American thoracic society. Am J Respir Crit Care Med. 1995;152(3):1107-1136.

30. Saleem I, Ali Z, Hussain H. Respiratory health implications among wet-blue leather tannery workers of Kasur. Nat Sci. 2021;20(3): e2021058.

31. Marçôa R, Rodrigues DM, Dias M, et al. Classification of chronic obstructive pulmonary disease (COPD) according to the new Global Initiative for Chronic Obstructive Lung Disease (GOLD) 2017: comparison with GOLD 2011. J Chron Obstruct Pulmon Dis. 2018;15 (1):21-26. 
32. Ferris B. Epidemiology standardization project. II. Recommended respiratory disease questionnaires for use with adults and children in epidemiological research. Am Rev Respir Dis. 1978;118(6):7-53.

33. Ishii S, Ashida N, Ohno H, et al. Noviherbaspirillum denitrificans sp. nov., a denitrifying bacterium isolated from rice paddy soil and Noviherbaspirillum autotrophicum sp. nov., a denitrifying, facultatively autotrophic bacterium isolated from rice paddy soil and proposal to reclassify Herbaspirillum massiliense as Noviherbaspirillum massiliense comb. nov. Int J Syst Evol Microbiol. 2017;67 (6):1841-1848.

34. Aisenberg G, Rolston KV, Safdar A. Bacteremia caused by Achromobacter and Alcaligenes species in 46 patients with cancer (1989-2003). Cancer. 2004;101(9):2134-2140.

35. Kavuncuoglu F, Unal A, Oguzhan N, Tokgoz B, Oymak O, Utas C. First reported case of Alcaligenes faecalis peritonitis. Peritoneal Dial Int. 2010;30(1):118-119.

36. Lundy F, Tunney M, Taggart C, Elborn J. Human Neutrophil Peptide-1 (HNP-1) and a truncated analogue display antimicrobial activity against respiratory pathogens. J Cystic Fibros. 2009;8:S47.

37. Cho HW, Byun J-H, Kim D, Lee H, Yong D, Lee KW. The first case of Ochrobactrum pseudogrignonense Bacteremia in Korea. Ann Lab Med. 2020;40(4):331-333.

38. Han XY, Hong T, Falsen E. Neisseria bacilliformis sp. nov. isolated from human infections. J Clin Microbiol. 2006;44(2):474-479.

39. Mezzatesta ML, Gona F, Stefani S. Enterobacter cloacae complex: clinical impact and emerging antibiotic resistance. Future Microbiol. 2012;7(7):887-902.

40. Struve C, Krogfelt KA. Pathogenic potential of environmental Klebsiella pneumoniae isolates. Environ Microbiol. 2004;6 (6):584-590.

41. Díez-Aguilar M, Ruiz-Garbajosa P, Fernández-Olmos A, et al. Nondiphtheriae Corynebacterium species: an emerging respiratory pathogen. Eur J Clin Microbiol Infect Dis. 2013;32(6):769-772.

42. Tada T, Miyoshi-Akiyama T, Dahal RK, et al. NDM-1 Metallo- $\beta$ Lactamase and ArmA 16S rRNA methylase producing Providencia rettgeri clinical isolates in Nepal. BMC Infect Dis. 2014;14(1):56.

43. Jiménez AS, van Tongeren M, Aitken RJ. Guidance for collection of inhalable and respirable Ni dust. IOM Rep. 2012;538. Avaiable form: https://www.nickelconsortia.eu/assets/files/library/Guidances/IOM\% 20Report\%201_inhalation\%20and\%20respirably\%20monitoring\% 20guidance\%20for\%20Ni_March\%202012.pdf.

44. Raisi L, Lazaridis M, Katsivela E. Relationship between airborne microbial and particulate matter concentrations in the ambient air at a Mediterranean site. Glob NEST J. 2010;12(1):84-91.

45. Brągoszewska E, Mainka A, Pastuszka JS. Concentration and size distribution of culturable bacteria in ambient air during spring and winter in Gliwice: a typical urban area. Atmosphere. 2017;8(12):239.

46. Chandrasekaran V, Dilara K, Padmavathi R. Pulmonary functions in tannery workers-a cross sectional study. Indian J Physiol Pharmacol. 2014;58(3):206-210. PMID: 25906602.

47. Shahzad K, Akhtar S, Mahmud S. Prevalence and determinants of asthma in adult male leather tannery workers in Karachi, Pakistan: a cross sectional study. BMC Public Health. 2006;6(1):292.

48. Were FH, Moturi MC, Wafula GA. Chromium exposure and related health effects among tannery workers in Kenya. $J$ Health Pollut. 2014;4(7):25-35.
49. Miyoshi-Akiyama T, Hayakawa K, Ohmagari N, Shimojima M, Kirikae T. Multilocus sequence typing (MLST) for characterization of Enterobacter cloacae. PLoS One. 2013;8(6):e66358.

50. Didilescu AC, Skaug N, Marica C, Didilescu C. Respiratory pathogens in dental plaque of hospitalized patients with chronic lung diseases. Clin Oral Investig. 2005;9(3):141-147.

51. Salvi SS, Barnes PJ. Chronic obstructive pulmonary disease in non-smokers. Lancet. 2009;374(9691):733-743.

52. Vogelmeier CF, Criner GJ, Martinez FJ, et al. Global strategy for the diagnosis, management, and prevention of chronic obstructive lung disease 2017 report. GOLD executive summary. Am J Respir Crit Care Med. 2017;195(5):557-582.

53. Hancox RJ, Gray AR, Poulton R, Sears MR. The effect of cigarette smoking on lung function in young adults with asthma. Am J Respir Crit Care Med. 2016;194(3):276-284.

54. Bardhan M, Sarkar M, Singh D, Negi R, Sharma S. Clinical and microbiological profile of patients with acute exacerbation of COPD. NJR. 2020;10(1):35-40.

55. Dalju I, Dessie A, Bogale L, Mekonnen TH. Occupational risk factors associated with respiratory symptoms among tannery workers in Mojo town, Southeast Ethiopia, 2018: a comparative cross-sectional study. Multidiscip Respir Med. 2019;14(1):1-10.

56. Jamal A, Mehmood A, Khatoon F, Putus T, Savolainen H, Liesivuori J. Prevalence of respiratory symptoms, bronchial asthma and obstructive lung disease among tannery workers. Ann Environ SciToxicol. 2017;2(1):033-042.

57. Stern FB. Mortality among chrome leather tannery workers: an update. Am J Ind Med. 2003;44(2):197-206.

58. Dalju I, Dessie A, Bogale L, Mekonnen TH. Occupational risk factors associated with respiratory symptoms among tannery workers in Mojo town, Southeast Ethiopia, 2018: a comparative cross-sectional study. Multidiscip Respir Med. 2019;14(1):27.

59. Miravitlles M. Cough and sputum production as risk factors for poor outcomes in patients with COPD. Respir Med. 2011;105 (8):1118-1128.

60. Rastogi SK, Pandey A, Tripathi S. Occupational health risks among the workers employed in leather tanneries at Kanpur. Indian J Occup Environ Med. 2008;12(3):132.

61. Yoh M, Matsuyama J, Ohnishi M, et al. Importance of Providencia species as a major cause of travellers' diarrhoea. J Med Microbiol. 2005;54(11):1077-1082.

62. Kaur CP, Vadivelu J, Chandramathi S. Impact of Klebsiella pneumoniae in lower gastrointestinal tract diseases. J Dig Dis. 2018;19 (5):262-271.

63. Hasan MJ, Nizhu LN, Rabbani R. Bloodstream infection with pandrug-resistant Alcaligenes faecalis treated with double-dose of tigecycline. IDCases. 2019;18:e00600.

64. Chmelař D, Holý O, Kasáková I, et al. Antibiotic susceptibility and production of endotoxin by Ochrobactrum anthropi isolated from environment and from patients with cystic fibrosis. Folia Microbiol (Praha). 2019;64(6):861-865.

65. Grzyb J, Lenart-Boroń A. Bacterial bioaerosol concentration and size distribution in the selected animal premises in a zoological garden. Aerobiologia. 2019;35(2):253-268. 


\section{Publish your work in this journal}

The International Journal of COPD is an international, peer-reviewed journal of therapeutics and pharmacology focusing on concise rapid reporting of clinical studies and reviews in COPD. Special focus is given to the pathophysiological processes underlying the disease, intervention programs, patient focused education, and self management protocols. This journal is indexed on PubMed Central, MedLine and CAS. The manuscript management system is completely online and includes a very quick and fair peer-review system, which is all easy to use. Visit http://www.dovepress.com/testimonials.php to read real quotes from published authors. 